\title{
Detection of copper ions using modified gold nanoparticles by two-functional groups
}

\author{
Bnar Ghazi Star ${ }^{1}$, Nahid Haghnazari ${ }^{2}$, Changiz Karami ${ }^{3}$ \\ ${ }^{1}$ University of Garmian, College of Science Chemistry Department. Kalar, Kurdistan Region, Iraq \\ ${ }^{2}$ Department of Medical Science, Sanandaj Branch, Islamic Azad University, Sanandaj, Iran \\ ${ }^{3}$ Department of Chemistry, Kermanshah Branch, Islamic Azad University, Kermanshah, Iran
}

Received 26 January 2021; revised 11 March 2021;

accepted 13 March 2021; available online 16 April 2021

doi: $10.24271 /$ psr.23

\begin{abstract}
In this study, gold nanoparticles were fabricated using two different functional groups such as crown ether and carboxylic acid and evaluated as a sensor to detect copper ions in an aqueous solution. The Au-crown/carboxylic is characterized with TEM, FTIR spectroscopy. To compare the response of the sensor to copper ions, the UV-vis spectrum was characterized before and after the increase of $\mathrm{Cu}^{2+}$ ions. The mechanism to be considered for measuring copper ions in aqueous solutions is that $\mathrm{Cu}^{2+}$ ions can successfully complexation with Au-crown/carboxylic which comes with color changes from red to blue. In the range of $75 \mathrm{nM}$ to $1250 \mathrm{nM}$, the link between the decrease in adsorption intensity and the concentration of $\mathrm{Cu}^{2+}$ ions at A630/A545 is linear with 0.9814 and $150 \mathrm{nM}$ correlation coefficient and the limit of detection, respectively. In other words, among several other cations, the sensor assay especially measures copper ions and also has very simple and able to measure and detect copper ions in an aqueous solution.
\end{abstract}

\section{(c) 2021 Production by the University of Garmian. This is an open access article under the LICENSE}

https://creativecommons.org/licenses/by-nc/4.0/

Keywords: Nano probe, sensor, crown ethers, carboxylic acid, copper (II)

\section{Introduction}

One of the most significant problems for researchers is the contamination of drinking water by heavy metals ${ }^{[1]}$. However cupper is one of the necessary elements for plants and animals but, its large amount is toxic for all creatures. Toxication with $\mathrm{Cu}^{2+}$ results in the headache, heart beats, kidney damage, liver diseases, hair falling, intestinal problems and anemia ${ }^{[2]}$. Several ways for the detection of heavy metals ions in different samples have been reported such as voltammetry ${ }^{[3]}$, ICP-AES ${ }^{[4]}$, ICPMS) ${ }^{[5]}$, and $\mathrm{AAS}^{[6]}$.

The simplicity and high sensitivity of nanoparticles as colorimetric assays have recently attracted increasing attention. Among the nanomaterials that are easily synthesized and applied, gold nanoparticles have a high molar extinction coefficient and are mostly used for colorimetric purposes of various targets ${ }^{[7,8]}$, e.g. DNA ${ }^{[9,10]}$, molecular Sensors [11], biosensors Based on Aptamers ${ }^{[12]}$, peptide ${ }^{[13]}$, proteins ${ }^{[14,15]}$ and metal ions ${ }^{[16]}$. The SPR is interesting properties because of can be ordered by changing its shape and size ${ }^{[17]}$. Gold nanoparticle-based color

* Corresponding author

E-mail address: bnar.ghaze.star@gmail.com (Instructor).

Peer-reviewed under the responsibility of the University of Garmian. sensors, which result from the association between particle plasmon and nanoparticle aggregation, change color from red to blue, which can be used for analysis ${ }^{[18,19]}$.

Here we present highly sensitive and selective probe for detection of copper (II) with colorimetric in aqueous solution and the gold nanoparticles synthesized in this study were modified with two different functional groups that enhance its ability to measure elements. (Scheme 1). the Au-crown/carboxylic nanoparticles was characterized by FT-IR, Uv-Vis spectrophotometer, TEM. The proposed mechanism for measuring copper ions forms a complex with each of the two or more modified copper ores, which causes the particles to come together and increase in diameter as the radius increases. The proposed mechanism for measuring copper ions is that with each copper ion with two or more modified gold nanoparticles form a complex, which causes the particles to aggregate and increase the diameter of the particles as a result the absorption wavelength has changed at A630/A545.

\section{Experimental section}

\section{1 Instruments}

The transmission electron microscopy (TEM) images were recorded by a Philips EM 208, at $100 \mathrm{kV}$. The FTIR spectra were recorded on Bruker (TENSOR 27) in range 400-4000 $\mathrm{cm}^{-1}$ wavenumber into $\mathrm{KBr}$ pellets. UV-vis spectrometer was recorded 
on Cary 100 UV-Visible, PH meter model 827, produced by Metrohm, with an accuracy of 0.001 for $\mathrm{pH}$, 6-liter ultrasonic bath model Elma (S60H) made in Germany.

\section{2 Materials}

High purity materials were used in the experiment. Hydrogen tetrachloroaurate (III) $\left(\mathrm{HAuCl}_{4} .4 \mathrm{H}_{2} \mathrm{O}, 99.99 \%\right)$, trisodium citrate dehydrate $\left(\mathrm{C}_{6} \mathrm{H}_{5} \mathrm{Na}_{3} \mathrm{O}_{7}-2 \mathrm{H}_{2} \mathrm{O}\right)$, L-cysteine $\left(\mathrm{C}_{3} \mathrm{H}_{7} \mathrm{NO}_{2} \mathrm{~S}\right)$, tetra methyl ammonium hydroxide (TMAOH), Benzo-15-crown-5ether, Phosphoryl chloride $\left(\mathrm{POCl}_{3}\right)$, Salts of the different cations studied $\left(\mathrm{B}\left(\mathrm{NO}_{3}\right)_{3}, \mathrm{BaCl}_{2}, \mathrm{FeCl}_{3}, \mathrm{AgNO}_{3}, \mathrm{~Pb}\left(\mathrm{NO}_{3}\right)_{2}, \mathrm{CoCl}_{2}\right.$, $\mathrm{Cr}\left(\mathrm{NO}_{3}\right)_{2}, \mathrm{MnCl}_{2}, \mathrm{Hg}_{2} \mathrm{Cl}_{2}, \mathrm{Hg}\left(\mathrm{NO}_{3}\right)_{2}$ and $\left.\mathrm{CuCl}_{2}\right)$.

\section{3 Synthesis of Au-nanoparticles}

Briefly, the solution of $\mathrm{HAuCl}_{4}(0.001 \mathrm{M})$ was heated until $80 \circ \mathrm{C}$ and stirred vigorously for $20 \mathrm{~min}$ then sodium citrate solution (15 $\mathrm{mM}, 100 \mathrm{~mL}$ ) was added drop by drop. Within this stage the black solution changed to reddish-brown gradually. After heating for extra $1 \mathrm{~h}$., the reaction mixture was cooled and collected ${ }^{[20]}$.

\section{4 Synthesis of Au-cysteine nanoparticles}

The obtained Au-nanoparticles $(100 \mathrm{mg}$ ) was dispersed in ethanol $(50 \mathrm{~mL})$ and treated by ultrasonic for $30 \mathrm{~min}$. After homogenizing the solution, cysteine $\left(5 \mathrm{~mL} \times 10^{-3} \mathrm{M}\right)$ was added and stirred for $24 \mathrm{~h}$ at room temperature. In this method, due to the fact that Lcysteine has thiol groups, citrate replaces with thiol of L-cysteine well on the surface of gold nanoparticles and forms a strong bond [21].

\section{5 Synthesis of Au-crown/carboxylic}

Dissolve the benzo-15-crown-5-ether $(1 \mathrm{mmol})$ in $5 \mathrm{~mL} \mathrm{DMF}$ and the mixture was cooled to $-5^{\circ} \mathrm{C}$, then phosphoryl chloride $\left(\mathrm{POCl}_{3}\right)$ ( $1 \mathrm{mmol}$ ) was added dropwise to the mixture. The mixture stirred at room temperature for about $1 \mathrm{~h}$, then the reaction mixture was refluxed for $4 \mathrm{~h}$. After cooling, it poured carefully onto ice. Product was dissolved in ethanol and then the mixture was added dropwise to Au-crown/carboxylic nanoparticles. The reaction mixture was refluxed in $\mathrm{N}_{2}$ atmosphere for two days. After nanoparticles were washed in ethanol and water, the product was dried.

\section{6 The $\mathrm{Cu}^{2+}$ ions colorimetric determination}

For colorimetric detection of copper(II) ions, the metal ions such as $\mathrm{Ba}^{2+}, \mathrm{Hg}^{2+}, \mathrm{B}^{+}, \mathrm{Hg}^{+}, \mathrm{Co}^{2+}, \mathrm{Ag}^{+}, \mathrm{Mn}^{2+}, \mathrm{Cu}^{2+}, \mathrm{Pb}^{2+}, \mathrm{Cr}^{2+}$ and $\mathrm{Fe}^{3+}$ at the same concentration $(200 \mathrm{nM})$ and the same conditions were added into $1.00 \mathrm{mg} \mathrm{Au}$-crown/carboxylic. The changing in the $\mathrm{UV} / \mathrm{vis}$ spectrum (A630 / A545) are monitored at room temperature

\section{7 The colorimetric detection of $\mathrm{Cu}^{2+}$ ions}

Different concentrations of $\mathrm{Cu}^{2+}$ with stirred at room temperature add to $0.33 \mathrm{mg} / \mathrm{mL}$ of Au-crown/carboxylic then stirred for 10 min, Record the absorption spectrum using a spectrophotometer and the concentration of $\mathrm{Cu}^{2+}$ ion to the ratio of absorbance of Au-crown/carboxylic at (A630/A545) was plotted.

\section{8 The effect of $\mathrm{pH}$}

Au-crown/carboxylic were added with $\mathrm{Cu}^{2+} 1 \mathrm{~mL}$ ions in $2.0 \mathrm{~mL}$ aqueous solution (10 millimolar $[\mathrm{mM}]$ buffer). The BrittonRobinson as a buffer and the $\mathrm{pH}$ value are in the range of 2 to 12

\section{Results and Discussion}

\section{1 Synthesis of Au-crown/carboxylic}

First, the synthesis of Au-crown/carboxylic was planned through the pathways shown in Scheme 1. Au is the soft acid and cysteine is soft bases (donor), therefore a strong covalent bond (Au-SR) occurs between $\mathrm{Au}$ and cysteine. Eventually, the N-terminal cysteine residues to react with ether crown aldehyde group to give imines ${ }^{[22]}$. Due to the fact that the carboxylic acid functional group is present in the cysteine ligand, so by placing crown ether on the surface of gold nanoparticles, it is modified with two groups.

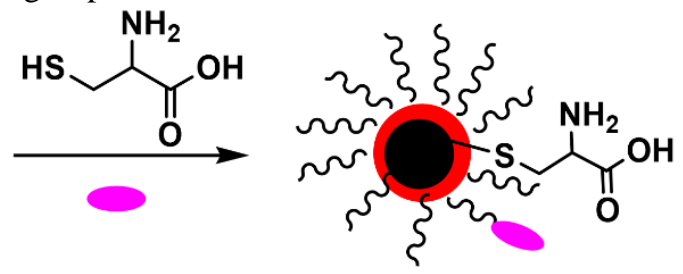

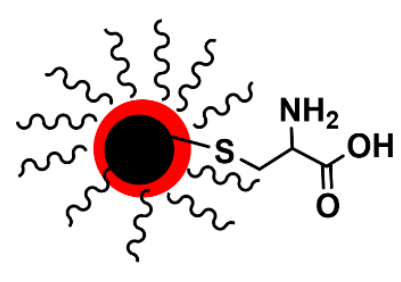
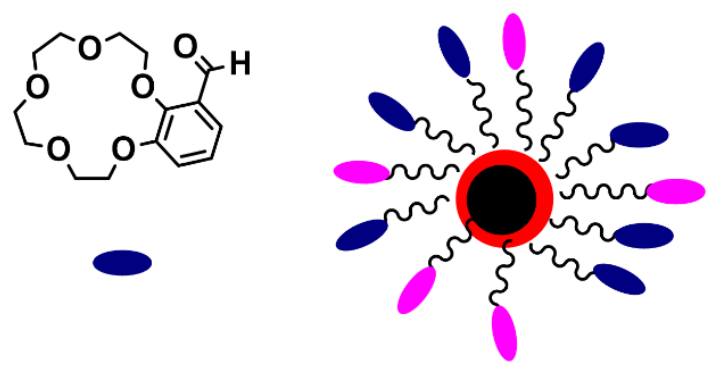

Scheme 1: Synthesis of Au-crown/carboxylic ligand.

Synthesized Au-crown/carboxylic were characterized by FTIR spectrum, UV-Vis absorption spectrum and transmission electronmicroscopy (TEM). Fig. 1 shows the UV-Vis absorption spectrum of Au-crown/carboxylic nanoparticles that the SPR at $545 \mathrm{~nm}$ is a clear evidence of synthesis of Au-crown/carboxylic nanoparticles ${ }^{[20]}$. 


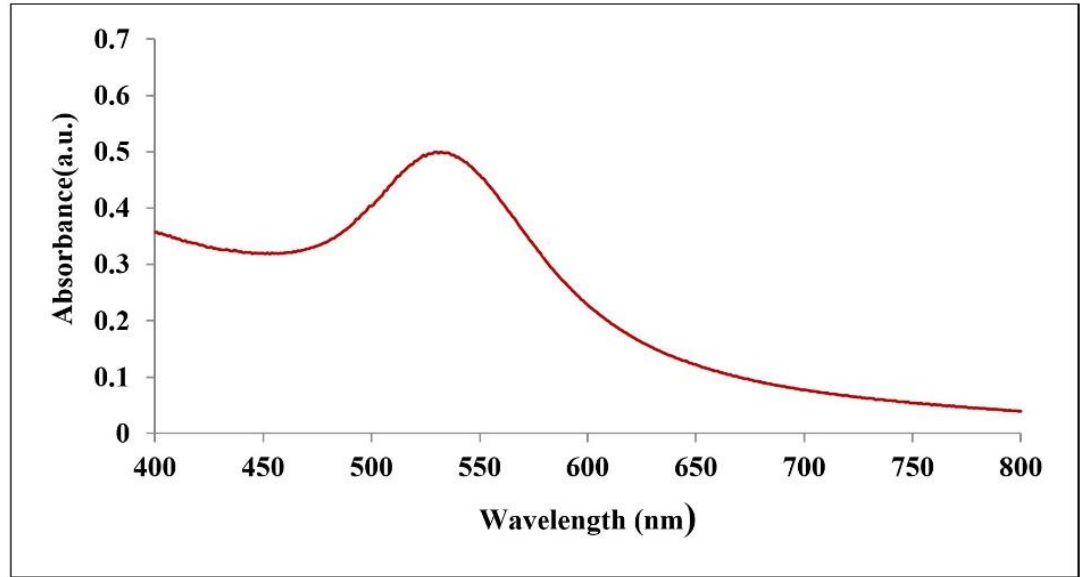

Figure 1: The UV-Vis absorption spectrum of Au-crown/carboxylic nanoparticles.

The Fig. 2a shows the TEM image of Au-crown/carboxylic nanoparticles that the images indicate $\mathrm{Au}$-crown/carboxylic nanoparticles and Fig. 2b shows the histogram of 100 randomly selected nanoparticles, so, most of the particles are between 1 and
5 nanometers, which is $50 \%$ of the total particles. It is obvious that synthesized NPs have an almost uniform size and there is not more dispersion.
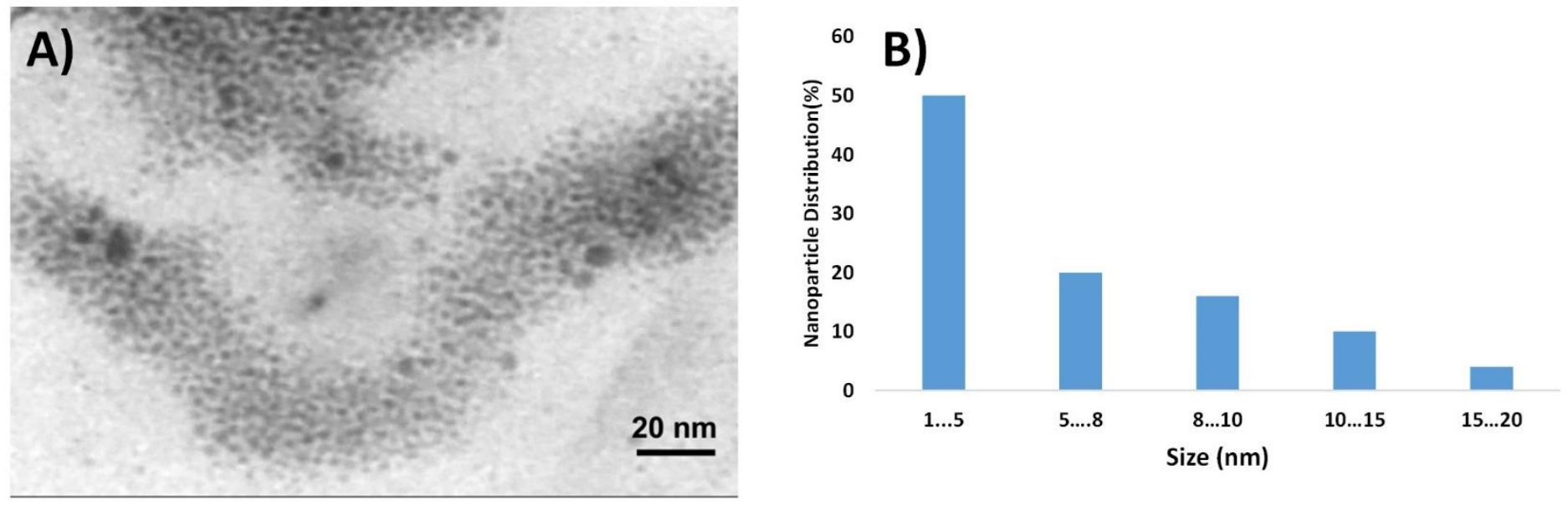

Figure 2: A) The TEM image of Au-crown/carboxylic nanoparticles with $20 \mathrm{~nm}$ scale bar, B) the histogram of 100 randomly selected nanoparticles

The FTIR spectra of Au-crown/carboxylic are presented in Fig.3. The signals observed at 3395 and $1731 \mathrm{~cm}^{-1}$ corresponds to $\mathrm{OH}$ stretch and the carbonyl stretch of a carboxylic acid group, in addition, two bands observed at $2977 \mathrm{~cm}^{-1}$ and $2841 \mathrm{~cm}^{-1}$ related to $\mathrm{C}-\mathrm{H}$ and $1625 \mathrm{~cm}^{-1}$ correlated to $\mathrm{C}=\mathrm{N}$ stretching vibrations $\mathrm{Au}-$ crown/carboxylic.

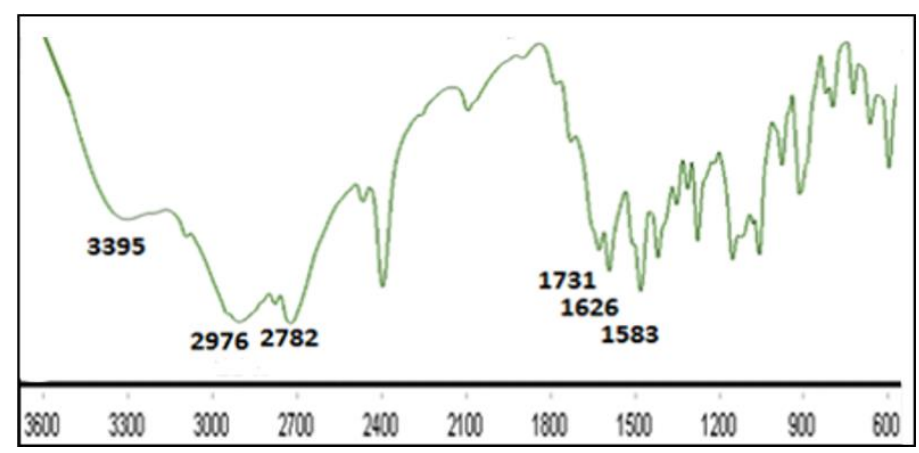

Figure 3: FT-IR spectra of Au-crown/carboxylic

\section{2 Metal ions sensing ability of Au-crown/carboxylic}

As mentioned above, Au-crown/carboxylic nanoparticles display obvious SPR. The SPR can be easily affected by various external factors, such as aggregation ${ }^{[23,24]}$. To investigate the various metals ions diagnosis ability of Au-crown/carboxylic nanoparticles, the same concentration of metal ions $(200 \mathrm{nM})$ were added the solution of Au-crown/carboxylic $(4 \mathrm{~mL})$. The Fig. 4 shows the SPR of Au-crown/carboxylic with metal ions. According to figure, which is based on A630/A545 absorbance ratio, this nano probe is so sensitive to copper than other elements.

Crown ethers are known for their strong tendency to form complexes with metals ions and most of these compounds have been used to identify specific metal ions ${ }^{[25,26]}$. In the other words, Crown ether are known for the unusual property of forming stable complexes with metal ions. Upon complexation with $\mathrm{Cu}^{2+}$ ions, the aggregation was happen in the surface of nanoparticles, so it is the best condition for Au-crown/carboxylic which leads to an 
increase in particles size. Therefore, it causes to change SPR or A630/A545 absorbance ratio. In this study, with aggregation in the surface of nanoparticles, the SPR or A630/A545 absorbance ratio was decreased, and the sediment of gold nanoparticle in the presence of $\mathrm{Cu}^{2+}$ ions due to aggregation is the reason of this decreasing ${ }^{[27,28]}$.

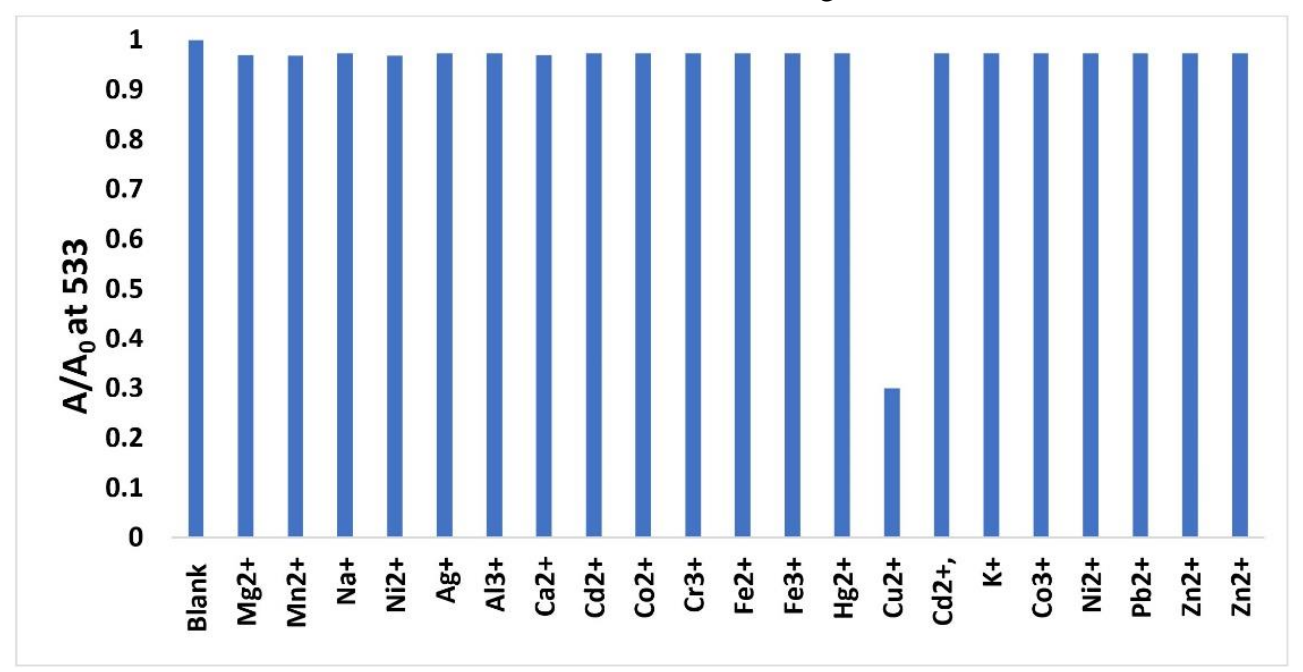

Figure 4: The UV-vis absorption of Au-crown/carboxylic in presence of different metal ions with same concentration $(200 \mathrm{nM})$ in $10 \mathrm{~min}$ and $25^{\circ} \mathrm{C}$

\section{3 Effect of $\mathrm{pH}$}

Optimal sensor conditions need to be studied for better performance. The effect of $\mathrm{pH}$ on absorbance spectrum and the absorption ratio of $1.00 \mathrm{mg} \mathrm{Au}$-crown/carboxylic in the presence of $\mathrm{Cu}^{2+}$ solution $(200 \mathrm{nM})$ in $10 \mathrm{~min}$ and $25^{\circ} \mathrm{C}$ show in the Fig. 5. The A630/A545 of Au-crown/carboxylic was constant and low in the $\mathrm{pH}$ range 4-8, so, it indicates that Au-crown/carboxylic were stable in these range of $\mathrm{pH}$. The absorbance ratio (A630/A545) of Au-crown/carboxylic significantly increased in $\mathrm{pH}$ range 9-11. As you well known, the heavy metals at $\mathrm{pH}>9$ is precipitated as metals hydroxide insoluble ${ }^{[29]}$, so we chose the $\mathrm{pH}$ at 7 range in this $\mathrm{pH}$ the A630/A545 ratio is the lowest value.

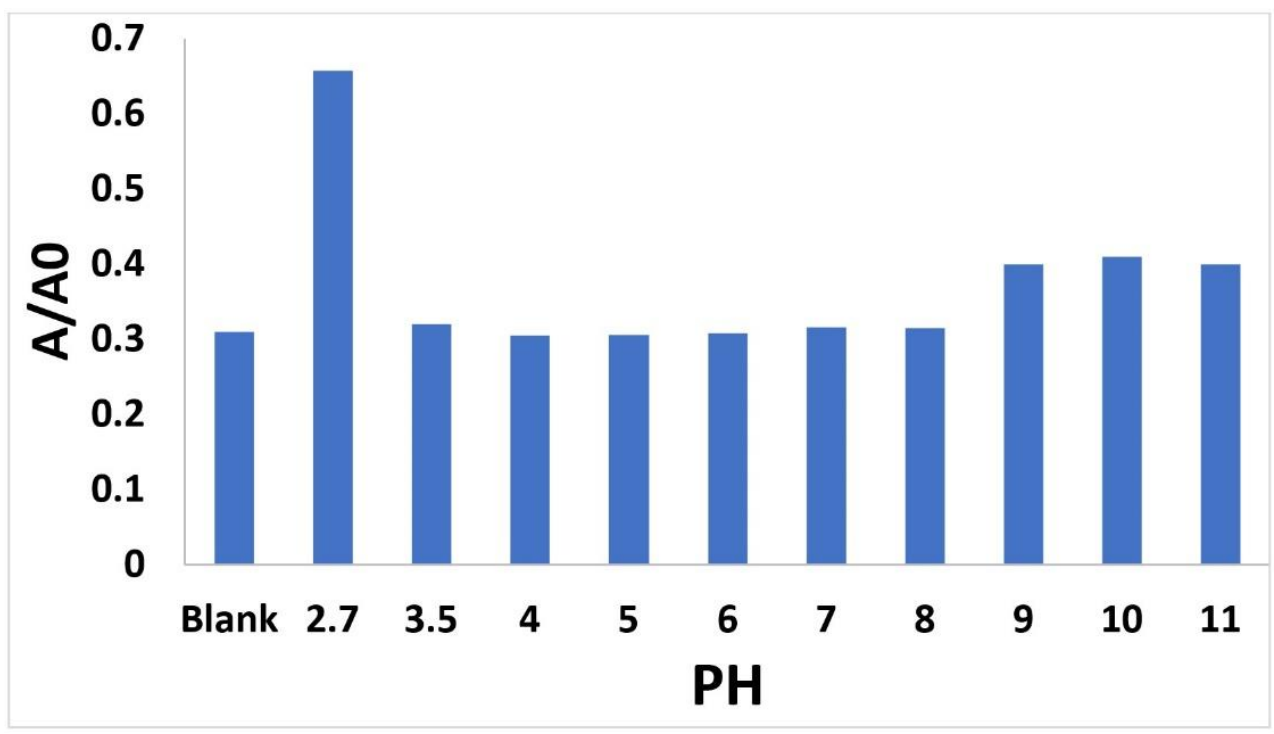

Figure 5: The effect of $\mathrm{pH}$ on the absorption ratio of $1.00 \mathrm{mg} \mathrm{Au}$-crown/carboxylic in the presence of $\mathrm{Cu} 2+$ solution $(200 \mathrm{nM})$ in $10 \mathrm{~min}$ and $25^{\circ} \mathrm{C}$

\section{4 Nano sensor evaluation}

For evaluation, the sensitivity of this sensor for $\mathrm{Cu}^{2+}$ detection, different concentrations of $\mathrm{Cu}^{2+}$ of ranging from 75 to $1250 \mathrm{nM}$ were used to this system. The Fig.6 shows changes in A630/A545 absorbance ratio with the addition of different concentrations $\mathrm{Cu}^{2+}$ ions to $1.00 \mathrm{mg} \mathrm{Au}$-crown/carboxylic in $10 \mathrm{~min}$ and $25^{\circ} \mathrm{C}$. The $\mathrm{A}_{630} / \mathrm{A}_{545}$ absorbance ratio decreased with increasing $\mathrm{Cu}^{2+}$ ions concentration. There is a linear relation between A630/A545 absorbance ratio and copper concentration in the range 75-1250 nanomolar $(\mathrm{nM})$ with a calibration equation of $\mathrm{y}=0.0005 \mathrm{x}+0.9593(\mathrm{r}=0.9814)$. The detection limit $(\mathrm{S} / \mathrm{N}$ ratio of 3 ) and sensitivity were $150 \mathrm{nM}$ and LOQ was calculated $500 \mathrm{nM}$. The Table 1 shows the linear range calibration sensitivity and detection limit of this sensor for copper determination. As it is 
shown, these factors are comparable and even better than those have been reported for other sensors ${ }^{[30-32]}$.

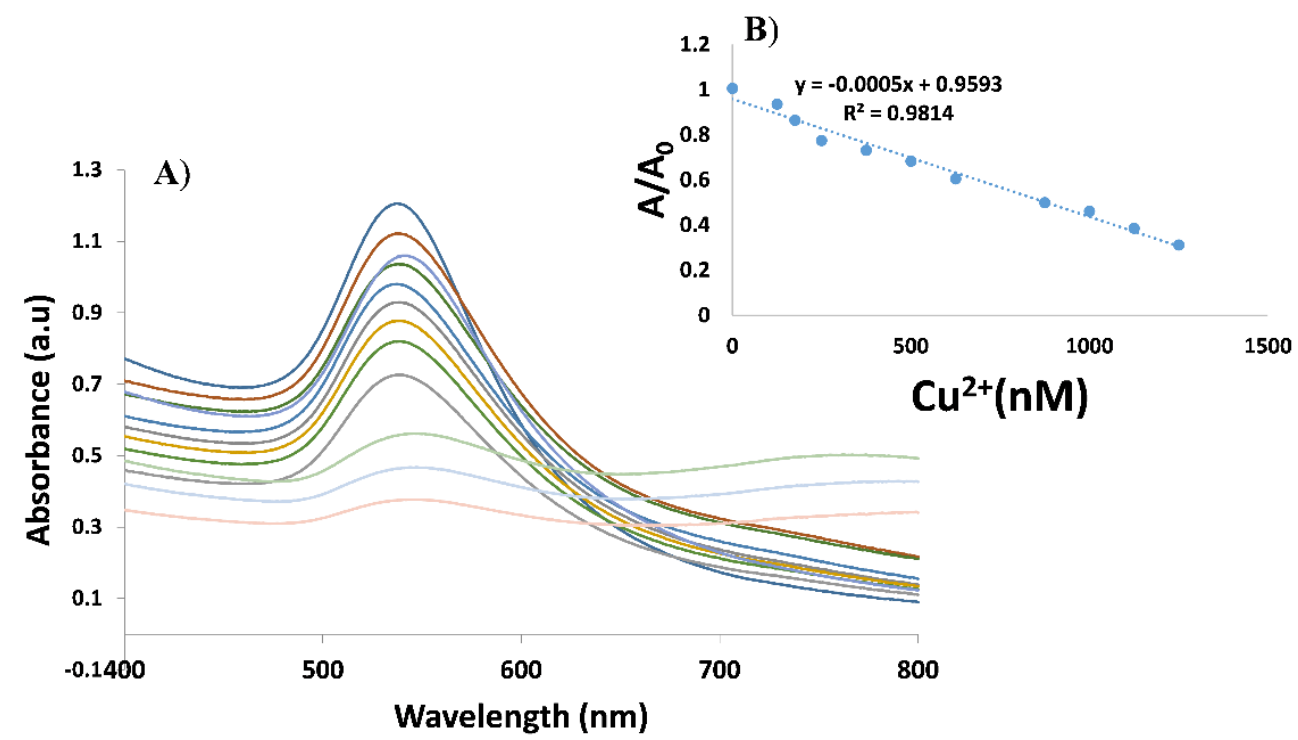

Figure 6: A) Change in surface plasmon resonance absorption of Au-crown/carboxylic in the presence of different concentrations from 75 to $1250 \mathrm{nM}$ of $\mathrm{Cu} 2+$ ion, $\mathrm{pH} 7.0, \mathbf{B})$ decrease in the relative sensitivity of the detection system with respect to the concentrat

Table1 : A comparison of various colorimetric assays for $\mathrm{Cu} 2+$ ions

\begin{tabular}{ccccc}
\hline Entry & Probe & LODs & Target & Refs \\
\hline 2 & unmodified gold nanoparticles & $10-0.1 \mu \mathrm{M}$ & $\mathrm{Cu}^{2+}$ & {$[30]$} \\
1 & Protein- AuNPs & $200 \mathrm{nM}$ & $\mathrm{Hg}^{2+}, \mathrm{Pb}^{2+}$ and $\mathrm{Cu}^{2+}$ & {$[31]$} \\
3 & Pyridines- AuNPs & --- & $\mathrm{Cu}^{2+}{\text { and } \mathrm{Ag}^{+}}^{2}$ & {$[32]$} \\
4 & Au-crown/carboxylic & $150 \mathrm{nM}$ & $\mathrm{Cu}^{2+}$ & this work \\
\hline
\end{tabular}

\section{5 Interference studies}

To check the selectivity of this sensor toward $\mathrm{Cu}^{2+}$ over other cations UV-Vis spectra of Au-crown/carboxylic nanoparticles modified in the presence of other metal ions containing $\mathrm{Mg}^{2+}$, $\mathrm{Mn}^{2+}, \mathrm{Cr}^{6+}, \mathrm{Co}^{3+}, \mathrm{Ni}^{2+}, \mathrm{Pb}^{2+}, \mathrm{Na}^{+}, \mathrm{Ni}^{2+}, \mathrm{Ag}^{+}, \mathrm{Al}^{3+}, \mathrm{Cr}^{3+}, \mathrm{Fe}^{2+}$,
$\mathrm{Fe}^{3+}, \mathrm{Ca}^{2+}, \mathrm{Cd}^{2+}, \mathrm{Co}^{2+}, \mathrm{Hg}^{2+}, \mathrm{Cd}^{2+}, \mathrm{K}^{+}$and $\mathrm{Zn}^{2+}$ were recorded. As demonstrated in Fig.7. The value of $\mathrm{A}_{630} / \mathrm{A}_{545}$ for to the mixture of $\mathrm{Cu}^{2+}$ with another metal ions was almost equal with $\mathrm{Cu}^{2+}$ ions. This shows that other metal ions did not interfere in the binding of $\mathrm{Au}-\mathrm{crown} /$ carboxylic with $\mathrm{Cu}^{2+}$ ions.

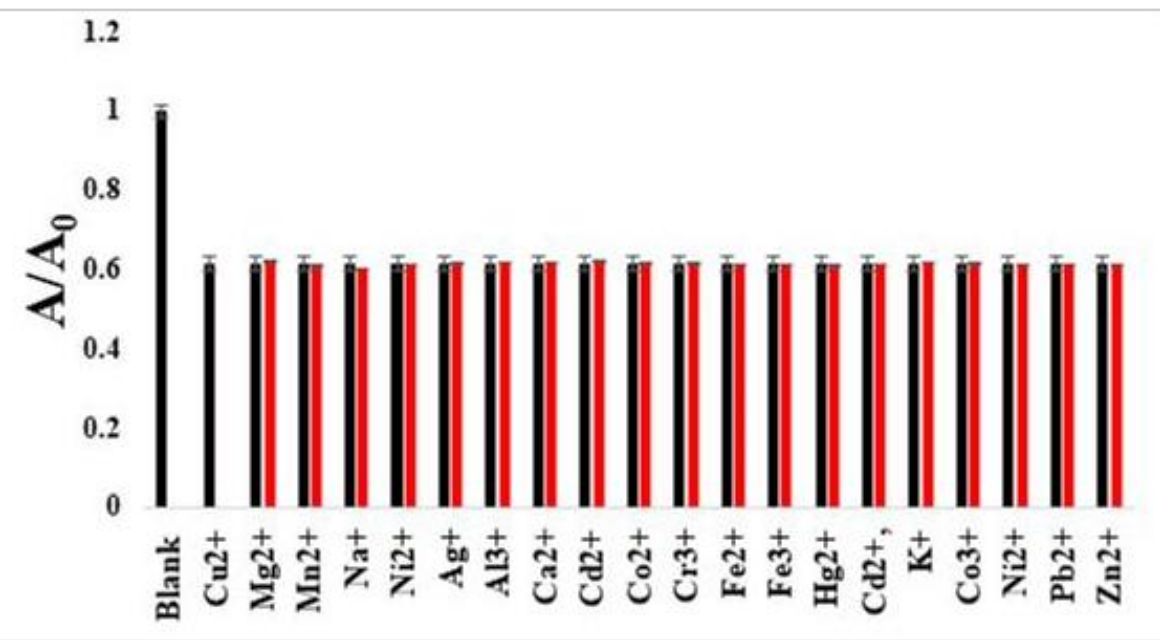

Figure 7: Absorbance ratio (A/A0) of Au-crown/carboxylic in the presence of metal ions. Red bars represent the addition of single metal ion; Blue bars represent the mixture of $\mathrm{Cu} 2+$ with another metal ions 


\section{6 Real samples}

To explore the applicability, the Au-crown/carboxylic in an analysis of $\mathrm{Cu}^{2+}$ ions in real samples including tap water was analyzed using the standard addition protocol ${ }^{[33-35]}$. As shown in Table 2, the recovery percentages of the spiked samples were in the range of $98.0-104.3 \%$ at admissible RSD values. Based on the results, the $\mathrm{Cu}^{2+}$ ions has a potential application in detection of $\mathrm{Cu}^{2+}$ ions in real water samples.

Table 2: Determination of concentration amounts of $\mathrm{Cu} 2+$ ions in water samples $(\mathrm{n}=5)$.

\begin{tabular}{ccccc}
\hline Sample & $\begin{array}{c}\text { Added } \\
(\mathbf{n M})\end{array}$ & $\begin{array}{c}\text { found } \\
(\mathbf{n M})\end{array}$ & $\begin{array}{c}\text { Recovery } \\
(\mathbf{\%})\end{array}$ & RSD\% \\
\hline 1 & 0 & - & - & - \\
2 & 100 & 9.8 & 98 & 3.02 \\
3 & 500 & 501.6 & 100.3 & 2.06 \\
4 & 1000 & 104.3 & 104.3 & 5.75 \\
\hline
\end{tabular}

\section{Conclusion}

In this research, a sensitive and selective method for the identification of copper ions based on colorimetric assay was designed by modifying the surface of gold nanoparticles by crown/carboxylic. Although Au-crown/carboxylic have a several advantages similar to other nano sensors first of all it is very sensitive with low detection limit and also is very easy to synthesis. In addition to, the crown ether in the surface of the $\mathrm{Au}$ crown/carboxylic is appropriate for complexation with $\mathrm{Cu}^{2+}$ ions. The complexation of Au-crown/carboxylic with $\mathrm{Cu}^{2+}$ will lead color and spectral change. Therefore, these changes in the adsorption and color of the nanoparticle solution can be related to the concentration of copper ions added and it can be easily detected in solutions and its exact value can be calculated. This method is a very useful and accessible method because it does not require complicated sophisticated equipment with high sensitivity and acceptable detection (LOD of $150 \mathrm{nM}$ ), that this amount is much lower than the maximum acceptable concentration of $\mathrm{Cu}^{2+}$ ions in water and drinking water. The results obtained and the impressive properties of the nano sensor make this proposed method, which is simple, fast and reliable, suitable for measuring the concentration of $\mathrm{Cu}^{2+}$ ions in an aqueous solution.

\section{Acknowledgements:}

We are thankful to the College of Medicine, University of Garmian of Kalar, Iraq for the support this work.

\section{References}

1. Cay S, Uyanık A, Özaşı A (2004) Single and binary component adsorption of copper (II) and cadmium (II) from aqueous solutions using tea-industry waste. Sep Purif Technol 38 (3):273-280

2. Tian Y, Wu M, Liu R, Li Y, Wang D, Tan J, Wu R, Huang Y (2011) Electrospun membrane of cellulose acetate for heavy metal ion adsorption in water treatment. Carbohydr Polym 83 (2):743-748

3. van den Berg CM (2006) Chemical speciation of iron in seawater by cathodic stripping voltammetry with dihydroxynaphthalene. Anal Chem 78 (1):156-163

4. Huber JK (1999) Determination of $\mathrm{Cu}, \mathrm{Fe}, \mathrm{Mn}$, and $\mathrm{Zn}$ in blood fractions by SECHPLC-ICP-AES coupling. Analyst 124 (5):657-663
5. Arnold GL, Weyer S, Anbar A (2004) Fe isotope variations in natural materials measured using high mass resolution multiple collector ICPMS. Anal Chem 76 (2):322-327

6. Andersen JE (2005) A novel method for the filterless preconcentration of iron. Analyst 130 (3):385-390

7. Zhao W, Brook MA, Li Y (2008) Design of gold nanoparticle-based colorimetric biosensing assays. ChemBioChem 9 (15):2363-2371

8. Wang G, Wang Y, Chen L, Choo J (2010) Nanomaterial-assisted aptamers for optical sensing. Biosens Bioelectron 25 (8):1859-1868

9. Han MS, Lytton-Jean AK, Oh BK, Heo J, Mirkin CA (2006) Colorimetric Screening of DNA-Binding Molecules with Gold Nanoparticle Probes. Angew Chem Int Ed 45 (11): $1807-1810$

10. Zhu X, Liu Y, Yang J, Liang Z, Li G (2010) Gold nanoparticle-based colorimetric assay of single-nucleotide polymorphism of triplex DNA. Biosens Bioelectron 25 (9):2135-2139

11. Al Shehab S, Patra D (2021) Binding of metal ions to the Curcumin mediated methoxy polyethylene glycol thiol conjugated greenly synthesized gold nanoparticles: A fluorescence spectroscopic study. Journal of Photochemistry and Photobiology A: Chemistry407:113083

12. Zhang F, Liu J (2021) Label-Free Colorimetric Biosensors Based on Aptamers and Gold Nanoparticles: A Critical Review. Analysis \& Sensing 1 (1):30-43

13. Sreelekshmi P, Lakshmi SA, Babu G, Devika V, Rajeev N, Sadanandan S (2020) Peptide dendrimer stabilized gold nanoparticles as sensors. Materials Today: Proceedings 26:382-386

14. Aili D, Selegård R, Baltzer L, Enander K, Liedberg B (2009) Colorimetric protein sensing by controlled assembly of gold nanoparticles functionalized with synthetic receptors. Small 5 (21):2445-2452

15. Xu Y, Wang J, Cao Y, Li G (2011) Gold nanoparticles based colorimetric assay of protein poly (ADP-ribosyl) ation. Analyst 136 (10):2044-2046

16. Meena R, Mehta VN, Bhamore JR, Rao PT, Park T-J, Kailasa SK (2020) Diaminodiphenyl sulfone as a novel ligand for synthesis of gold nanoparticles for simultaneous colorimetric assay of three trivalent metal cations $(\mathrm{Al} 3+, \mathrm{Fe} 3+$ and Cr3+). J Mol Liq 312:113409

17. Li S, Liu X, Liu Q, Chen Z (2020) Colorimetric Differentiation of Flavonoids Based on Effective Reactivation of Acetylcholinesterase Induced by Different Affnities between Flavonoids and Metal Ions. Anal Chem 92 (4):3361-3365

18. Karami C, Mehr SY, Deymehkar E, Taher MA (2017) Naked Eye Detection of Cr3+ and $\mathrm{Co} 2+$ Ions by Gold Nanoparticle Modified with Azomethine. Plasmonics:1-8

19. Karami C, Taher MA (2017) Colorimetric Sensor of Cobalt Ions in Aqueous Solution Using Gold Nanoparticles Modified with Glycyrrhizic Acid. Plasmonics:1-9

20. Zhu X, Yang H, Wang N, Zhang R, Song W ,Sun Y, Duan G, Ding W, Zhang Z (2010) A facile method for preparation of gold nanoparticles with high SERS efficiency in the presence of inositol hexaphosphate. J Colloid Interface Sci 342 (2):571-574

21. Karamipour S, Sadjadi M, Farhadyar N (2015) Fabrication and spectroscopic studies of folic acid-conjugated Fe $3 \mathrm{O} 4 @$ Au core-shell for targeted drug delivery application. Spectrochimica Acta Part A: Molecular and Biomolecular Spectroscopy 148:146-155

22. Fotoohi B, Mercier L (2015) Some insights into the chemistry of gold adsorption by thiol and amine functionalized mesoporous silica in simulated thiosulfate system. Hydrometallurgy 156:28-39

23. Garcia M, De la Venta J, Crespo P, Llopis J, Penadés S, Fernández A, Hernando A (2005) Surface plasmon resonance of capped Au nanoparticles. Physical Review B 72 (24):241403

24. Lin S-Y, Liu S-W, Lin C-M, Chen C-h (2002) Recognition of potassium ion in water by 15-crown-5 functionalized gold nanoparticles. Anal Chem 74 (2):330-335

25. Pearson RG (1963) Hard and soft acids and bases. J Am Chem Soc 85 (22):3533-3539 
26. Alizadeh A, Khodaei M, Karami C, Workentin M, Shamsipur M, Sadeghi M (2010) Rapid and selective lead (II) colorimetric sensor based on azacrown etherfunctionalized gold nanoparticles. Nanotechnology 21315503:(31)

27. Pedersen CJ (1988) The discovery of crown ethers (Noble Lecture). Angew Chem Int Ed 27 (8):1021-1027

28. Khan MN, Wahab MF (2007) Characterization of chemically modified corncobs and its application in the removal of metal ions from aqueous solution. J Hazard Mater 141 (1):237-244

29. Albrecht TWJ, Addai-Mensah J, Fornasiero D (2011) Effect of pH, concentration and temperature on copper and zinc hydroxide formation/precipitation in solution. Chemeca 2011: Engineering a Better World: Sydney Hilton Hotel, NSW, Australia, 18-21 September 2011:2100

30. Zhang L-p, Xing Y-p, Liu C, Zhou X-h, Shi H-c (2015) Label-free colorimetric detection of $\mathrm{Cu} 2+$ on the basis of Fenton reaction-assisted signal amplification with unmodified gold nanoparticles as indicator. Sensors and Actuators B: Chemical 215:561-567

31. Guo Y, Wang Z, Qu W, Shao H, Jiang X (2011) Colorimetric detection of mercury, lead and copper ions simultaneously using protein-functionalized gold nanoparticles. Biosens Bioelectron 26 (10):40644069-

32. Alizadeh A, Khodaei MM, Hamidi Z, Bin Shamsuddin M (2014) Naked-eye colorimetric detection of $\mathrm{Cu} 2+$ and $\mathrm{Ag}+$ ions based on close-packed aggregation of pyridines-functionalized gold nanoparticles. Sensors and Actuators B: Chemical 190:782-791

33. Karami C, Taher MA (2019) A novel enzyme-less amperometric sensor for hydrogen peroxide based on nickel molybdate nanoparticles. J Electroanal Chem 847:113219

34. Baghayeri M, Veisi H, Farhadi S, Beitollahi H, Maleki B (2018) Ag nanoparticles decorated $\mathrm{Fe} 3 \mathrm{O}$ 4/chitosan nanocomposite: synthesis, characterization and application toward electrochemical sensing of hydrogen peroxide. Journal of the Iranian Chemical Society 15 (5):1015-1022

35. Star BG, Shahlaei M, Karami C (2021) A novel fluorescent turn-on probe for hydrogen peroxide based on carbon dots. Journal of Materials Science: Materials in Electronics:1-9 